\title{
Feeding ecology of a nocturnal invasive alien lizard species, Hemidactylus mabouia Moreau de Jonnès, 1818 (Gekkonidae), living in an outcrop rocky area in southeastern Brazil
}

\author{
Rocha, CFD.* and Anjos, LA. \\ Departamento de Ecologia, Instituto de Biologia Roberto Alcântara Gomes, \\ Universidade do Estado do Rio de Janeiro - UERJ, CEP 20550-013, Rio de Janeiro, RJ, Brazil \\ *e-mail: cfdrocha@uerj.com.br \\ Received October 25, 2005 - Accepted December 5, 2005 - Distributed August 31, 2007
}

(With 2 figures)

\begin{abstract}
We studied in fieldwork, the feeding ecology of a Hemidactylus mabouia population from southeastern Brazil throughout one year in a region with marked climatic seasonality. A sampling of availability of arthropods in the environment was carried out, which evidenced that the availability of food resources influenced the composition of the diet of H. mabouia. There were no seasonal differences on diet composition, which may be due to the relatively constant availability on prey throughout the year. In general, this population can be classified as generalist and opportunistic regarding diet. There was a high food niche overlap among juveniles and adults, although juvenile lizards tend to eat higer number of prey (but in lower volume) when compared to adult lizards. The ability to exploit a wide array of prey in an efficient way, maintaining a positive energetic balance, may be a factor determining the efficiency of this exotic species to occupy invaded areas.
\end{abstract}

Keywords: diet, exotic species, Hemidactylus, Valinhos.

\section{Ecologia alimentar de uma espécie invasora noturna de lagarto, Hemidactylus mabouia, vivendo em um campo ruderal no sudeste do Brasil}

\begin{abstract}
Resumo
Estudamos a ecologia alimentar de uma população de Hemidactylus mabouia do sudeste do Brasil ao longo de um ano, em uma região com sazonalidade climática marcada. Foi realizada uma amostragem dos artrópodes no ambiente, o que permitiu constatar que a disponibilidade das presas influenciou a composição da dieta de H. mabouia. Não houve diferenças sazonais na composição da dieta, o que pode resultar de uma constância na disponibilidade de presas ao longo do ano. De modo geral, os dados mostraram que esta população estudada é generalista e oportunista quanto a sua dieta. Houve uma elevada sobreposição de nicho trófico, porém os lagartos jovens tenderam a ingerir uma quantidade maior de presas (porém de menor volume) quando comparados aos lagartos adultos. A capacidade de explorar de maneira eficiente os recursos locais, mantendo um balanço energético positivo, pode ser um fator responsável pela habilidade de colonização desta espécie exótica vivendo na natureza.
\end{abstract}

Palavras-chave: dieta, espécie exótica, Hemidactylus, Valinhos.

\section{Introduction}

Invasive alien (or exotic) species constitute a great problem for natural environments and for native species and it has been suggested that after habitat fragmentation, they are the second most important factor causing the loss of biodiversity and extinctions in most areas worldwide (Vitousek et al., 1997; Mooney and Hoobs, 2000; Sutherst, 2000; McNeely et al., 2001). The spread of invasive alien species is creating complex and farreaching challenges that threaten both the natural biological world and the well being of citizens (McNeely et al., 2001). Presently, many countries are working together in a "Global strategy on Invasive Alien Species" de-

signed to cope with the problem caused by these species (McNeely et al., 2001). One limiting factor preventing better understanding of the nature of the problem caused locally and the subsequent management of invasive species, is the lack of information on aspects of the ecology of those species and on their interaction with sympatric native species, especially in the field.

The gecko Hemidactylus mabouia is a broadly distributed species in the tropics which has invaded the New World after accidental introductions from its Old World native range in historic times, probably via slave ships coming from Africa during European coloniza- 
tion of the Americas (Ávila-Pires, 1995, Federico and Cacivio, 2000; Fuenmayor et al., 2005). This species has proven to be a very successful invader species in the Americas and presently is largely distributed in southern North America, as well as in Central and South America (Fuenmayor et al., 2005). Despite its successful colonization, little information regarding aspects of its ecology exists and, especially for the New World, ecological information obtained from non-urban populations is considerably limited, which prevents a better understanding of its impact as an invader on native species. At Valinhos, in São Paulo State, in southeastern Brazil, a population of $H$. mabouia live in nature in an outcrop rock area dominated by grassland, sharing food resources with local native species such as Tropidurus itambere (Van Sluys, 1993) and Mabuya frenata (Vrcibradic and Rocha, 1998).

In this paper we investigate in the field the feeding ecology of a non-urban population of Hemidactylus mabouia, a species known for its generalist feeding habits (cf. Vitt, 1995; Zamprogno and Teixeira, 1998; Rocha et al., 2002). The population studied lives in a non-urban area (Valinhos) with marked climatic seasonality, in Southeastern Brazil. We specifically addressed the following questions: i) as expected for an invader species, does this population of $H$. mabouia have a broad diet? ii) is there a seasonal variation in the types of consumed prey considering the seasonal environment of Valinhos? iii) is the rate of prey consumption a function of relative availability of prey in the environment? iv) does the diet composition of adult and juvenile lizards differ in terms of the consumption of the commonest food items? and v) to what extent is the diet composition of this invader similar to that of the local native species T. itambere and M. frenata for which diet information is available? Also, regarding the positive energetic balance of this population, we would expect a considerable amount of lizards to have an empty stomach, according to the assumption that geckonid lizards, mainly nocturnal ones, tend to evidence a high rate of individuals with an empty stomach, as pointed by Huey et al. (2001).

\section{Material and Methods}

Fieldwork was carried out from April 2002 to March 2003 in a grassland area located within a farm (Fazenda Manga) in Valinhos municipality (22 56' S and $46^{\circ} 55^{\prime} \mathrm{W}$; elevation ca. $700 \mathrm{~m}$ ), São Paulo State, southeastern Brazil. The general area, which is mostly used for pasture, has abundant granite boulders surrounded by grassy and shrubby vegetation (Van Sluys, 1993; Vrcibradic and Rocha, 1998). The rainy season in Valinhos extends from October to March and the dry season from April to September, and the mean annual temperature $( \pm \mathrm{sd})$ and total annual rainfall are $20.7 \pm 2.2^{\circ} \mathrm{C}$ and $1379 \mathrm{~mm}$, respectively (Van Sluys et al., 1994). During the period of this study, rainfall totalized $230 \mathrm{~mm}$ in the dry season and $1047 \mathrm{~mm}$ in the wet season (Figure 1) [all climatic data were obtained
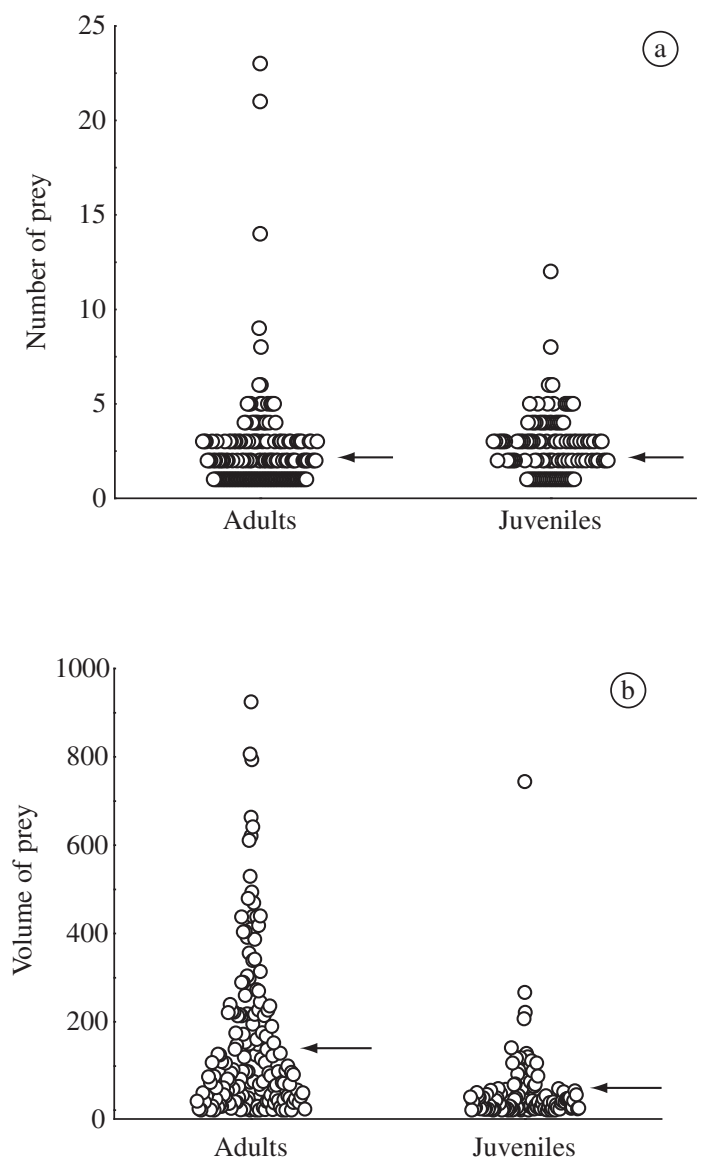

Figure 1. a) Number of prey found in the stomachs of adults and juveniles of Hemidactylus mabouia sampled at Valinhos, São Paulo State, between April 2002 and March 2003. Arrows indicate the mean number of prey found in the stomachs of adult (2.6 prey) and juvenile ( 2.7 prey) (Mann-Whitney; $\mathrm{U}=7420.5 ; \mathrm{p}<0.05 ; \mathrm{n}=275$ ).; and $\mathrm{b}$ ) Volume of prey found in the stomachs of adults and juveniles of Hemidactylus mabouia sampled at Valinhos, São Paulo State, between April 2002 and March 2003. Arrows indicate the mean volume of prey found in the stomachs of adults $\left(147.6 \mathrm{~mm}^{3}\right)$ and juveniles $\left(40.9 \mathrm{~mm}^{3}\right)$ (Mann-Whitney; $\mathrm{U}=4668.0 ; \mathrm{p}<0.001 ; \mathrm{n}=275$ ).

from the Centre for Research in Agriculture (CEPAGRI) of the Universidade Estadual de Campinas].

Lizards were collected with a noose or by hand. Immediately after capture, each lizard was transferred to a plastic sack containing cotton embedded in ether, in order to anesthetize and euthanaze them. In the laboratory, we measured the snout-vent length (SVL), head width (HD), head length (HL) and mouth length (ML) of each individual with a caliper (to the nearest $0.01 \mathrm{~mm}$ ) prior to fixation with $10 \%$ formalin solution and storage in $70 \%$ alcohol solution. To evaluate the difference in body size between adult males and adult females, we used the Student- $t$ test (Zar, 1999). The lizards were later dissected and their stomachs were removed for posterior 
analyses of their contents under a stereomicroscope. For analyses, we only considered the items present in the stomachs. The stomach contents were identified to the taxonomic level of Order, except for Hymenoptera, for which we separated ants (Formicidae) from the rest of the group. The contents that could not be identified were pooled into a "non-identified" category. The volume (in $\mathrm{mm}^{3}$ ) of each food item was estimated by the formula of the volume of an "ellipsoid":

Volume $=4 / 3 \pi \times(L / 2) \times(W / 2)^{2}$

where $L=$ length and $W=$ width. The length and the width of each prey was measured with a caliper (to the nearest $0.01 \mathrm{~mm}$ ).

We estimated the Importance Value Index (IVI) to each prey category (Gadsden and Palacios-Orona, 1997). The IVI index took into consideration together the proportions of the number, volume and frequency of occurrence of each category of prey.

The food niche breadth was estimated by the Shannon Diversity Index, H', (Krebs, 1989). Additionally, we estimated the standardized diversity index $\left(\mathrm{H}_{\mathrm{p}}\right)$ by sharing the H' by $\mathrm{H}_{\text {MAX }}$ (maximum value of H') (Krebs, 1989). The standardized index range is from 0 to 1 and allows a more efficient comparison of sexual and ontogenetic variation of dietary niche breadth.

To estimate the relative availability of potential prey in the field (and to obtain a reference collection of prey - cf. Van Sluys, 1991), we sampled arthropods in the environment. The samples were carried out only during the time of lizard activity, and in the same microhabitat (granite rocky surfaces) used by the lizards in the area. To determine the available arthropods, we used an entomological suction glass provided with a hose of $9.0 \mathrm{~mm}$ diameter. The diameter of the hose was similar to the maximum aperture diameter of the lizard's mouth, which limited the maximum volume of the arthropods sampled to a size nearest to maximum size of the prey found in the lizard stomachs. Each arthropod sampling session lasted five minutes and during this period the largest possible area of the surface of the rock was sampled. The relative arthropod abundance was estimated by the number of individuals of each species, divided by the total number of arthropods sampled at the study area.

To evaluate the seasonal, intersexual and ontogenetic differences in proportions of prey categories (in terms of number and volume) consumed by lizards, we used the Kolmogorov-Smirnov Test (Zar, 1999).

We used Analysis of Variance (One-Way ANOVA) to test for intersexual and ontogenetic differences in mean number and mean volume of prey consumed by $H$. mabouia (excepting for ontogenetic differences in mean volume of prey, in which case we performed a Mann-Whitney test, due to the fact that these data do not fit a normal distribution)

To evaluate the relationship between the proportion of food items consumed by the lizards and their proportion in the environment, we performed a spearman rank correlation (Zar, 1999). The same test was applied to evaluate the relationship between lizard size (SVL) and the mean size of the five largest prey (size and volume). On each stomach we performed a Spearman Rank Correlation (Zar, 1999).

We used Pianka's measure of niche overlap (Pianka, 1973) to determine the diet similarity between adult and juvenile lizards and between males and females:

$$
O_{12}=O_{21}=\frac{\sum_{i=1}^{n} P 2 i P 1 i}{\sqrt{\left(\sum_{i}^{n} p 2 i^{2}\right)\left(\sum_{i}^{i} p 1 i^{2}\right)}}
$$

where $\mathrm{P}_{2 \mathrm{i}}$ and $\mathrm{P}_{1 \mathrm{i}}$ are the rate of consumption of prey type $i$ by sexes 1 and 2 respectively. We compared the observed overlap value against a null model (1000 interactions) generated by the algorithm of randomization R3 (Lawlor, 1980) using the software ECOSIM 7.0 (Gotelli and Entsminger, 2001). This same methodology was used to compare the overlap between dietary items for another two sympatric lizards, T. itambere and M. frenata, for which some diet data are available in the literature (Van Sluys, 1993; Vrcibradic and Rocha, 1998).

\section{Results}

We collected 291 individuals of H. mabouia ( 87 adult males, 85 adult females and 119 juveniles). Of these, 14 lizards (4.8\%) had no food items in their stomachs. Regarding the empty stomachs, seven $(50 \%)$ were from adult males, three $(21.4 \%)$ were from adult females and four $(28.6 \%)$ were from juveniles. There was no significant difference in SVL between adult males (56.7 \pm $5.0 \mathrm{~mm}$; range $=46.9-68.2 \mathrm{~mm} ; \mathrm{n}=87)$ and adult females $(56.6 \pm 5.2 \mathrm{~mm}$; range $=47.9-67.2 \mathrm{~mm} ; \mathrm{n}=85)$ (Student- $t$ test; $t=-0.231 ; \mathrm{p}>0.05$ ).

The diet consisted mainly of arthropods, comprising 19 orders of insects, two orders of arachnids, and one of both, crustaceans and gastropods (Mollusca) (Table 1). In terms of number, the dominant prey in the diet of H. mabouia were spiders $(22.4 \%)$, insect larvae $(9.8 \%)$ and termites $(9.1 \%)$, whereas in terms of volume, cockroaches predominated $(29.4 \%)$, followed by grasshoppers $(19.1 \%)$ and spiders $(15.6 \%)$ (Table 1$)$. The most frequent prey in diet were spiders $(44.0 \%)$, insect larvae $(22.5 \%)$ and grasshoppers (18.5\%) (Table 1). According to the Importance Value Index (IVI), the most important items consumed were spiders (0.819), followed by cockroaches $(0.537)$, insect larvae $(0.457)$ and grasshoppers (0.449) (Table 1).

The overall mean number of prey in the stomach contents was $2.6 \pm 2.3(1-23, \mathrm{n}=277)$ and this number did not differ significantly between adult males $(2.4 \pm 2.8$, $\mathrm{n}=80)$ and adult females $(2.8 \pm 2.7, \mathrm{n}=82)$ (ANOVA; $\left.\mathrm{F}_{1,160}=0.718 ; \mathrm{p}=0.40\right)$. Similarly, the mean volume of prey consumed by $H$. mabouia was $103.7 \pm 155.5 \mathrm{~mm}^{3}$ $\left(0.1-924 \mathrm{~mm}^{3}, \mathrm{n}=277\right)$ and the mean prey volume did not differ between adult males $\left(162.4 \pm 183.9 \mathrm{~mm}^{3}\right.$, 
Table 1. General composition of diet of Hemidactylus mabouia $(\mathrm{n}=291)$ expressed in terms of number $(\mathrm{N})$, frequency $(\mathrm{F})$, volume $\left(\mathrm{V}\right.$, in $\left.\mathrm{mm}^{3}\right)$ and importance value index (IVI) of each prey category. Adults and juvenile lizards were collected between April 2002 and March 2003 at Valinhos, São Paulo State.

\begin{tabular}{|c|c|c|c|c|c|c|c|}
\hline Taxon & $\mathbf{N}$ & $(\%)$ & $\mathbf{F}$ & $(\%)$ & V & $(\%)$ & IVI \\
\hline \multicolumn{8}{|l|}{ MOLLUSCA } \\
\hline Gastropoda & 9 & 1.2 & 8 & 2.9 & 64 & 0.2 & 0.043 \\
\hline \multicolumn{8}{|l|}{ ARACNIDAE } \\
\hline Aranae & 165 & 22.4 & 121 & 44.0 & 4610 & 15.6 & 0.819 \\
\hline Pseudoscorpionida & 4 & 0.5 & 4 & 1.5 & 21 & 0.1 & 0.021 \\
\hline \multicolumn{8}{|l|}{ INSECTA } \\
\hline Blattaria & 53 & 7.2 & 47 & 17.1 & 8690 & 29.4 & 0.537 \\
\hline Blattaria: nymph & 1 & 0.1 & 1 & 0.4 & 8 & 0.0 & 0.005 \\
\hline Coleoptera & 13 & 1.8 & 13 & 4.7 & 624 & 2.1 & 0.086 \\
\hline Collembola & 7 & 0.9 & 5 & 1.8 & 2 & 0.0 & 0.028 \\
\hline Dermaptera & 1 & 0.1 & 1 & 0.4 & 17 & 0.1 & 0.006 \\
\hline Diplopoda & 3 & 0.4 & 3 & 1.1 & 202 & 0.7 & 0.022 \\
\hline Diptera & 14 & 1.9 & 12 & 4.4 & 42 & 0.1 & 0.064 \\
\hline Hemiptera & 10 & 1.4 & 10 & 3.6 & 111 & 0.4 & 0.054 \\
\hline Hemiptera: nymph & 5 & 0.7 & 5 & 1.8 & 63 & 0.2 & 0.027 \\
\hline Homoptera & 58 & 7.9 & 48 & 17.5 & 955 & 3.2 & 0.285 \\
\hline Homoptera: nymph & 4 & 0.5 & 4 & 1.5 & 5 & 0.0 & 0.020 \\
\hline Hymenoptera & 21 & 2.8 & 4 & 1.5 & 126 & 0.4 & 0.047 \\
\hline Hymenoptera: Formicidae & 40 & 5.4 & 18 & 6.5 & 623 & 2.1 & 0.141 \\
\hline Isoptera & 67 & 9.1 & 19 & 6.9 & 661 & 2.2 & 0.182 \\
\hline Insect larvae & 72 & 9.8 & 62 & 22.5 & 3969 & 13.4 & 0.457 \\
\hline Lepidoptera & 46 & 6.2 & 42 & 15.3 & 828 & 2.8 & 0.243 \\
\hline Mantodea & 14 & 1.9 & 14 & 5.1 & 981 & 3.3 & 0.103 \\
\hline Neuroptera:larva & 1 & 0.1 & 1 & 0.4 & 20 & 0.1 & 0.006 \\
\hline Orthoptera & 53 & 7.2 & 51 & 18.5 & 5664 & 19.1 & 0.449 \\
\hline Orthoptera: nymph & 8 & 1.1 & 3 & 1.1 & 71 & 0.2 & 0.024 \\
\hline Psocoptera & 13 & 1.8 & 11 & 4.0 & 12 & 0.0 & 0.058 \\
\hline Trychoptera & 3 & 0.4 & 3 & 1.1 & 16 & 0.1 & 0.016 \\
\hline \multicolumn{8}{|l|}{ CRUSTACEA } \\
\hline Isopoda & 19 & 2.6 & 10 & 3.6 & 249 & 0.8 & 0.071 \\
\hline Isopoda: nymph & 1 & 0.1 & 1 & 0.4 & 0 & 0.0 & 0.005 \\
\hline non identified & 33 & 4.5 & 31 & 11.3 & 942 & 3.2 & 0.189 \\
\hline Total & 738 & 100.0 & 275 & 100.0 & 29579 & 100.0 & - \\
\hline
\end{tabular}

$\mathrm{n}=80)$ and adult females $\left.145.5 \pm 175.4 \mathrm{~mm}^{3}, \mathrm{n}=82\right)$ (ANOVA; $\mathrm{F}_{1,160}=0.360 ; \mathrm{p}=0.55$ ). There was no significant difference between the mean number of prey consumed by adult lizards $(2.6 \pm 2.8 ; \mathrm{n}=162)$ and juvenile lizards $\left(2.8 \pm 1.7 ; \mathrm{n}=113\right.$; ANOVA; $\mathrm{F}_{1,273}=0.505$; $\mathrm{p}=0.478)$. On the other hand, the mean volume of prey consumed by adult lizards $\left(153.9 \pm 179.3 \mathrm{~mm}^{3} ; \mathrm{n}=162\right)$ was significantly higher than that consumed by juvenile lizards (41.9 $\pm 81.8 \mathrm{~mm}^{3}, \mathrm{n}=113$ ) (Mann-Withney Test, $\mathrm{U}=4668.0 ; \mathrm{p}<0.001 ; \mathrm{n}=275)$.

The diet composition of adult males and females did not differ in terms of number of (Kolmogorov-Smirnov; $\left.\mathrm{D}_{\mathrm{MAX}}=0.100 ; \mathrm{p}>0.05\right)$ nor in volume of prey consumed $\left(D_{\text {MAX }}=0.100 ; p>0.05\right)$. Further, there was no signifi- cant difference in the diet composition between adult lizards (pooled males and females) and juveniles in terms of number $\left(\mathrm{D}_{\mathrm{MAX}}=0.100 ; \mathrm{p}>0.05\right)$ and volume $\left(D_{\text {MAX }}=0.333 ; p>0.05\right)$ of prey consumed.

Considering the arthropods sampled in the environment, the more representative groups were ants, termites, hemipterans and orthopterans (Figure 2) with a diversity value of $\mathrm{H}^{\prime}=2.31\left(\mathrm{H}_{\text {MAX }}^{\prime}=0.74\right)$. The proportion of each arthropod taxon sampled in the environment did not differ between dry and wet seasons (Kolmogorov-Smirnov; DMAX $=0.217 ; \mathrm{p}>0.05$ ).

The diet composition of $H$. mabouia was positively related to the relative availability of arthropods in the environment, both in terms of number (Spearman Rank 


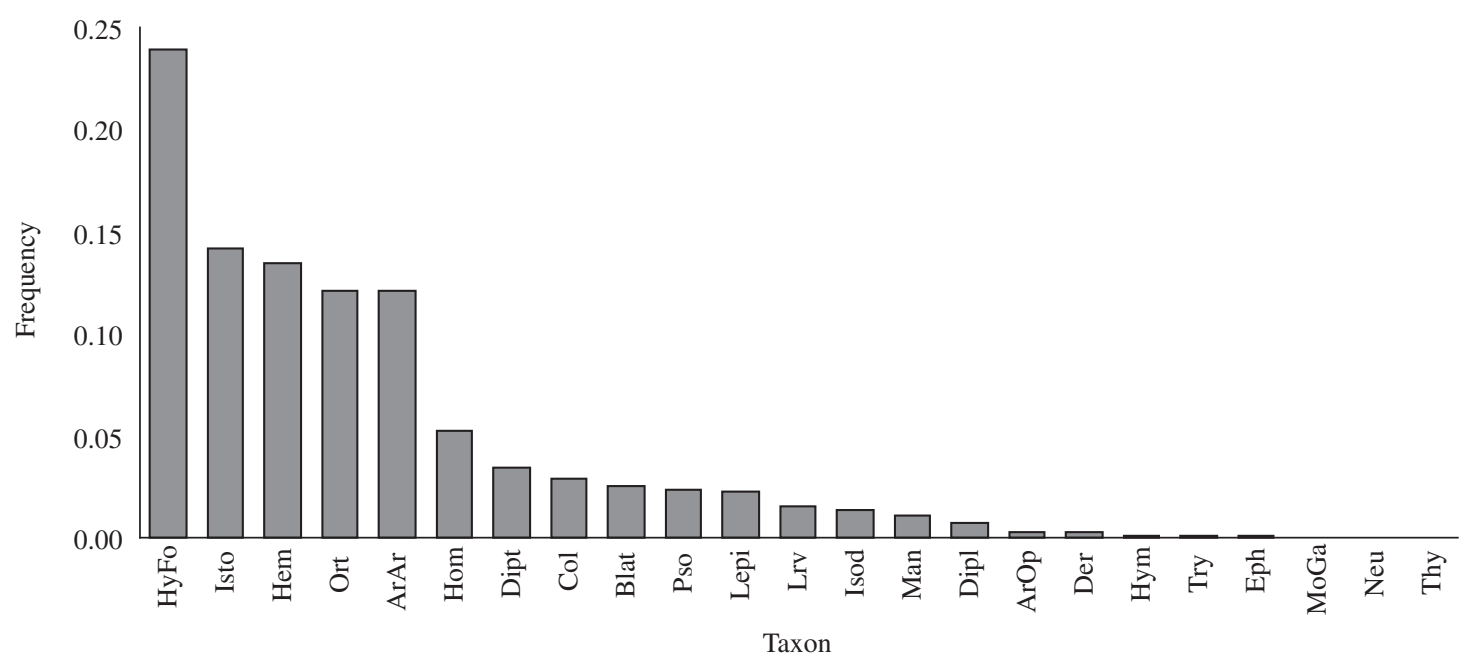

Figure 2. Relative abundance of arthropods, potential prey of Hemidactylus mabouia, sampled in an outcrop area in Valinhos, São Paulo State. HyFo = Hymenoptera Formicidae; Isto = Isoptera; Hem = Hemiptera; Ort = Orthoptera; ArAr = Aracnidae Aranae Hom = Homoptera $;$ Dipt $=$ Diptera Col = Coleoptera; Blat = Blattaria Pso = Psocoptera; Lepi $=$ Lepidoptera; Lrv = larva; Isod = Isopoda; Man = Mantodea; Dipl = Diplopoda; ArOp = Aracnida Opilionida; Der = Dermaptera; Hym = Hymenoptera; Try = Trychoptera Eph = Ephemeroptera; MoGa = Mollusca gastropoda; Neu = Neuroptera; Thy = Thysanura.

Correlation; $\mathrm{rs}=0.689 ; \mathrm{p}<0.001$; df. $=25)$ and frequency ( $\mathrm{rs}=0.799 ; \mathrm{p}<0.001$; df. $=25$ ) of prey types. Additionally, the frequency distribution of prey types found in the stomachs did not differ from that of potential prey sampled in the environment (KolmogorovSmirnov; $\left.\mathrm{D}_{\text {MAX }}=0.231 ; \mathrm{p}>0.05\right)$.

Hemidactylus mabouia had a food niche breadth of H'p $=0.76\left(\mathrm{H}^{\prime}=2.62\right)$, with that of adult females $\left(\mathrm{H}^{\prime} \mathrm{p}=0.81, \mathrm{H}^{\prime}=2.5\right)$ being similar to that of adult males $\left(H^{\prime} p=0.80, H^{\prime}=2.39\right)$ and of juveniles $\left(H^{\prime} p=0.75\right.$, $\left.H^{\prime}=2.48\right)$. The food niche overlap between adult males and females both in terms of number $\left(O_{12}=O_{21}=0.790\right)$ and by volume $\left(O_{12}=O_{21}=0.940\right)$, were larger than expected by chance (Number of prey, RA3, p < 0.01 ; Volume of prey, RA3, p < 0.01). Similarly, the food niche overlap between adults and juvenile lizards by number $\left(O_{12}=O_{21}=0.886\right)$ and volume $\left(O_{12}=O_{21}=0.749\right)$ were higher than expected by chance (Number of prey, RA3, $\mathrm{p}<0.001$; Volume of prey, RA3, $\mathrm{p}<0.05)$.

Concerning the food niche overlap between H. mabouia and two other sympatric lizards, the overlap between $H$. mabouia and M. frenata was $34.0 \%$ (in terms of number of prey) and in terms of volume of prey, the overlap was $32.87 \%$ (RA3, p < 0.05 ). With respect to $H$. mabouia and $T$. itambere, the food niche overlap in terms of volume of prey was $38.1 \%$ (RA3, p < 0.05). The data to number of prey consumed by $T$. itambere were not available in Van Sluys (1993). The overlap between two diurnal lizards, $M$. frenata and T. itambere was the higher $\left(O_{12}=O_{21}=0.472\right.$, in terms of volume, RA3, p < 0.05) concerning these three sympatric species.

There was no correlation between lizard body size and volume (Spearman Rank Correlation, $r_{s}=0.456$; $\mathrm{p}>0.05, \mathrm{n}=276)$, length $\left(\mathrm{r}_{\mathrm{s}}=0.407 ; \mathrm{p}>0.05, \mathrm{n}=276\right)$ and mean diameter $\left(r_{s}=0.432 ; \mathrm{p}>0.05, \mathrm{n}=276\right)$ of the five (or less) largest prey consumed by lizards.

\section{Discussion}

In general, our data indicated that the population of Hemidactylus mabouia from Valinhos is generalist and opportunistic regarding its diet. The diet of this population consisted essentially of several arthropods and was similar to that of other Brazilian H. mabouia populations studied (Vitt, 1995; Zamprogno and Teixeira, 1998; Rocha et al., 2002).

The diet composition did not show any seasonal changes, which can be related to a relative constancy of prey availability throughout the year in the area, combined with the opportunistic foraging behavior of this lizard. Similarly to our study, Vrcibradic et al. (1998) during a study in the same area also, did not find a significant variation in abundance of arthropods throughout the year.

The data showed that the composition of the diet did not vary between adult males and females, not even in ontogenetic terms. This may result from the fact that adult and juvenile lizards, which are opportunistic predators and are active at the same time, also use the same microhabitat (surface of rocks) in Valinhos, being potentially exposed to a similar array of prey. Also, there were no significant size differences (neither in morphologic differences of the mouth) between adult males and females of $H$. mabouia from Valinhos, which may have contributed to the high trophic niche overlap found between the sexes. 
The slightly higher value of diversity (H'p) of prey in adults compared to juveniles and the greater food niche overlap between adults compared to juveniles may be due to the inclusion of some few prey types by adults in their diet, which are not available to juveniles, due to their mouth size restrictions relative to adults. It is known that, for most lizard species, adults tend to consume similar food items utilized by juvenile lizards, just adding new items to their diets as they grow (Pough et al., 1998).

The data show a general tendency of juveniles to consume a higher number of prey, but less voluminous when compared to adult lizards. This must result from the constraints to consume some larger prey due to their volume, which is imposed by morphological limitation in mouth size (width and breadth) of juvenile lizards. As smaller lizards are limited by mouth size and have to consume comparatively smaller prey when compared to adult lizards, they must invest in the consumption of a higher number of prey in order to maintain a favorable energetic balance. For the tropical tropidurid lizard Liolaemus lutzae, the number of prey in the stomach decreases with body size (Rocha, 1989). To be energetically profitable to a lizard, the prey should contain more energy than that dispended by the predator in searching, subjugating and swallowing them (Rocha, 1989).

The energetic balance of a particular lizard population can be estimated by the proportion of individuals having empty stomachs (Huey et al., 2001). Nocturnal lizard species tend to show higher proportions of individuals with empty stomachs $(24.1 \%)$ when compared to diurnal ones (10.5\%; Huey et al., 2001). This pattern remains when diurnal $(7.2 \%)$ and nocturnal geckonids (21.2\%) are compared (Huey et al., 2001). The H. mabouia population from Valinhos presented a relatively small proportion of individuals with empty stomachs $(4.8 \%)$. This proportion was similar to that found in another H. mabouia population in Espírito Santo State (4.6\%; Zamprogno and Teixeira, 1998), and considerably lower than that reported for the cogeneric H. turcicus (13.5\%) (Saenz, 1996), and also generally lower than those values recorded for nocturnal geckonids by Huey et al. (2001).

The proportion of empty stomachs found for H. mabouia from Valinhos when compared to those from other nocturnal geckonids (see Huey et al., 2001) is suggestive that the population of this study may be in a better positive energetic balance than other geckonids. This may result from the relative constancy in the availability of prey throughout the year in the area and the generalist habits of the species, together with the fact that $H$. mabouia is the only nocturnal lizard species in the area. It is possible that these characteristics, which tend to result in a relatively favorable energetic balance, as found in the present study and in that of Zamprogno and Teixeira (1998), may contribute in an important way to the colonization success of this exotic species.

Interspecific competition can be inferred when the overlapping of resources used by two species living in al- lopatry are higher than the overlapping of resources when the species are living in simpatry (Colwell and Futuyma, 1971). The dietary niche breadth of $H$. mabouia living in simpatry with another nocturnal gekkonid (Phyllopezus pollicaris) in the Caatinga (a semi-arid shrubby physiognomy) of northeast Brazil (Vitt, 1995) seems to be lower (based on number and proportion of category of consumed prey) than the dietary niche breadth found in this population of H. mabouia of Valinhos (H'p $=0.76$; $\mathrm{H}^{\prime}=2.62$ ). The values of niche overlapping found by Vitt (1995) for that two species of geckonid $\left(O_{12}=60.8 \%\right)$ were also inferior to dietary overlap values between males and females $\left(O_{12}=79.0 \%\right)$ in the population of H. mabouia studied here. This may be an indication that, even considering the high similarity in diet composition between males and females, the effect of intersexual competition in this species seems to be low.

The overlap in diet niche between $H$. mabouia and two other sympatric lizards were lower than intraspecific overlap in $H$. mabouia. These results could be due to a temporal separation in time activity between nocturnal (H. mabouia) and diurnal species (T. itambere and $M$. frenata) and by differential preferences in microhabitat use (Van Sluys, 1991; Vrcibradic and Rocha, 1998). We can accept that this invader geckonid has been partitioning some food resources with sympatric native species.

The diet composition of nocturnal lizards associated to human buildings could differ (in terms of category of prey consumed) between populations that inhabit urban environments and those living in natural ones (Hódar and Pleguezuelos, 1999). The diet composition of a Mourish gecko population (Tarentola mauritanica) living in nature, was compared with that of a population living in an urban environment (Hódar and Pleguezuelos, 1999). Their results indicated that the diet composition of the two populations differed basically by the presence of winged groups (such as lepidopterans and dipterans), which presented in higher number and frequency in the diets of lizards from urban areas. Similarly, the most important food items in the diet of H. mabouia populations living in natural environments (Vitt, 1995; Zamprogno and Teixeira, 1998; present study) were spiders, orthopterans, homopterans and eruciforms larvae, whereas in an urban population of $H$. mabouia from Campinas city, close to Valinhos, the most important items in diet were winged insect groups such as dipterans and winged hymenopterans (Ariedi-Jr et al., 2001), which probably are attracted by the artificial illumination of residences.

We conclude that the generalist and opportunistic feeding habits of the $H$. mabouia population from Valinhos, together with the relative constancy in the local abundance of prey among seasons, result in a positive energetic balance of the studied population.

Acknowledgments - We thank those from the Fazenda Manga who permitted the first author to work in the area, and Vagner Ariedi Jr. and Jivanildo P. Miranda for fieldwork assistance on some occasions during the study. Dr. Arício X. Linhares and 
Ricardo Ribeiro for the identification of some prey items. MC Kiefer and D Vrcibradic for their valuable suggestions regarding this manuscript. The study was supported by research grants from the Conselho Nacional de Desenvolvimento Científico e Tecnológico - CNPq to LAA (Process 130651/2002-8) and from CFDR (Processes no. 307653/2003-0 and no. 477981/2003-8). IBAMA (Process no. 02027.012935/02-036)

\section{References}

ARIEDI-JR, VR, KIEFER, MC and MANZANI, PR., 2001. Dieta da lagartixa Hemidactylus mabouia (Squamata, gekkonidae) em ambiente periantrópico na região de Campinas, SP. $1^{o}$ Simpósio da Sociedade Brasileira de Herpetologia. Instituto Butantan, São Paulo.

ÁVILA-PIRES, TCS., 1995. Lizards of Brazilian Amazonia (Reptilia: Squamata). Zool. Verh. Leiden, vol. 299, p. 1-706.

COLWELL, RK. and FUTUYMA, DJ., 1971. On the measurement of niche breadth and overlap. Ecology, vol. 52, no. 4 , p. $567-576$.

FEDERICO, L., and CACIVIO, PM., 2000. Geographic distribution, Hemidactylus mabouia. Herp. Rev., vol. 31, no. 1, p. 53.

FITCH, H., 1978. Sexual size differences in the genus Scelopurus. Univ. Kansas Sci. Bull., vol. 51, p. 441-461.

FUENMAYOR, GR., UGUETO, GN., BAUER, A, BARROS, T. and MANZANILLA, J., 2005. Expansion and Natural History of a successful colonizing gecko in Venezuela (Reptilia: Gekkonidae: Hemidactylus mabouia) and the discovery of H. frenatus in Venezuela. Herp. Rev., vol. 36, no. 2, p. 121-125.

GADSDEN, HE. and PALACIOS-ORONA, LE., 1997. Seasonal Dietary Patterns of the Mexican fringe-toed Lizard (Uma paraphygas). J. Herpetol., vol. 31, no. 1, p. 1-9.

GOTELLI, NJ. and ENTSMINGER, GL., 2001. EcoSim: Null models software for ecology. Version 7.0. Acquired Intelligence Inc. \& Kesey-Bear.

HÓDAR, JA. and PLEGUEZUELOS, JM., 1999. Diet of the Moorish gecko Tarentola mauritanica in an arid zone of SouthEastern Spain. Herpet. Jour., vol 9, no. 1, p. 29-32.

HUEY, RB. and PIANKA, ER., 1983. Temporal separation of activity and interspecific dietary overlap. In HUEY, RB., PIANKA, ER., and SCHOENER, TW. (eds.), Lizards Ecology, Harvard University Press, 1983.

HUEY, RB., PIANKA, ER. and VITT, LJ., 2001. How often do lizards "run on empty"? Ecology, vol. 82, no. 1, p. 1-7.

KREBS, CJ., 1989. Ecological Methodology. Harper Collins Publishers, New York.

LAWLOR, LR., 1980. Structure and stability in natural and randomly constructed competitive communities. Am. Nat., vol. 116, no. 3, p. 394-408.

MCNEELY, JA., MOONEY, HA., NEVILLE, LE., SCHEI, P. and WAAGE, JK. (eds.), 2001. A Global Strategy on Invasive Alien Species. IUCN Gland, Switzerland, And Cambridge, UK., in collaboration with the Global Invasive Species Programme. $50 \mathrm{pp}$.
MOONEY, HA. and HOOBS, RJ., 2000. Invasive species in a changing world, Island Press, Washington.

PIANKA, ER., 1973. The structure of lizard communities. Ann. Rev. Ecol. Syst., vol. 4, p. 53-74.

POUGH, FH., ANDREWS, RM., CADLE, JE., CRUMP, ML., SAVITZKY, AH., and WELLS, KD., 1998. Herpetology. Prentice Hall.

ROCHA, CFD., 1989. Diet of a tropical lizard (Liolaemus lutzae) of southeastern Brazil. J. Herpetol., vol. 23, no. 3, p. 292-294.

ROCHA, CFD., DUTRA, GF., VRCIBRADIC, D. and MENEZES, VA., 2002. The terrestrial reptile fauna of the Abrolhos Archipelago: Species list and ecological aspects. Braz. J. Biol., vol. 62, no. 2, p. 285-291.

SAENZ, D., 1996. Dietary overview of Hemidactylus turcicus with possible implications of food partitioning. J. Herpetol, vol. 30 , no. 4 , p. 461-466.

SUTHERST, RW., 2000. Climate change and invasive species: a conceptual framework. p. 211-240 In MOONEY, HA. and HOOBS, RJ. (eds.), Invasive species in a changing world, Island Press, Washington.

VAN SLUYS, M., 1991. Dieta de Tropidurus itambere Rodrigues (Sauria; Iguanidae) na Fazenda Manga, município de Valinhos, São Paulo. (Dissertação de Mestrado) - Inst. Biologia, Universidade Estadual de Campinas, 65p.

-, 1993, Food habits of the lizard Tropidurus itambere (Tropiduridae) in Southeastern Brazil. J. Herpetol., vol. 27, no. 3, p. 347-351.

VAN SLUYS, M, ROCHA, CFD. and. RIBAS, SC., 1994, Nematodes infecting the lizard Tropidurus itambere in southeastern Brazil. Amph.-Rep., vol. 15, p. 405-408.

VITOUSEK, PM., D'ANTONIO, CM., LOOPE, LL., RÉJMANEK, M. and WESTBROOKS, R., 1997. Introduced species: a significant component of human-caused global change. New Zealand J. Ecol., vol. 21, no. 1, p. 1-16.

VITT, LJ., 1995. The ecology of tropical lizards in the Caatinga of northeast Brazil. Occ. Pap. Okla. Mus. Nat. Hist., vol. 1, p. 1-29.

VRCIBRADIC, D. and ROCHA, CFD., 1998. The ecology of skink Mabuya frenata in an area of rock outcrops in southeastern Brazil. J. Herpetol., vol. 32, no. 2, p. 229-237.

VRCIBRADIC, D., ROCHA, CFD., TELES, GM. and VAN SLUYS, M., 1998. Dieta conservativa em um ambiente sazonal: o caso de Mabuya frenata (Sauria, Scincidae) em Valinhos, SP. Anais do VIII Seminário Regional de Ecologia, vol. II, p. 857-867, UFSCar, São Carlos, SP.

ZAMPROGNO, C. and TEIXEIRA, RL., 1998. Hábitos alimentares da lagartixa de parede Hemidactylus mabouia (Reptilia, Gekkonidae) da planície litorânea do norte do Espírito Santo, Brasil. Rev. Bras. Biol., vol. 58, no. 1, p. 143-150.

ZAR, J., 1999, Biostatistical Analyses. Prentice-hall, Inc, Upper Saddle River 
